\title{
Składki na ubezpieczenia społeczne za pracowników zatrudnionych w Polsce i wykonujących pracę na podstawie umów cywilnoprawnych $\mathrm{w}$ innym państwie członkowskim UE
}

Social insurance contributions for the persons employed in Poland and working on the basis of civil law contracts in another EU Member State

Streszczenie. Ustalenie ustawodawstwa właściwego dla opłacania składek na ubezpieczenia społeczne za pracowników zatrudnionych w Polsce i wykonujących pracę na podstawie umów cywilnoprawnych w innym państwie członkowskim UE jest uzależnione od prawidłowego zakwalifikowania rodzaju aktywności jako najemnej albo wykonywanej na własny rachunek z uwzględnieniem polskich regulacji o zbiegu tytułów ubezpieczeń społecznych i nakazu traktowania całego dochodu tych osób tak, jakby był uzyskiwanym w danym państwie.

Słowa kluczowe: praca najemna; umowa cywilnoprawna; składki. 


\begin{abstract}
Determination of the legislation applicable to the payment of social insurance contributions for the persons employed in Poland and working on the basis of civil law contracts in another EU Member State depends on the correct qualification of the given type of an activity. It can be classified either as an activity of an employed person or as an activity of a self-employed person, taking into consideration Polish rules on overlapping of social insurance titles and the directive to treat all their incomes as if they were received in the Member State concerned.
\end{abstract}

Keywords: activity as an employed person; civil law contracts; contributions.

\title{
1. Wprowadzenie
}

Temat opłacania składek na ubezpieczenia społeczne za pracowników zatrudnionych w Polsce i wykonujących pracę na podstawie umów cywilnoprawnych w innym państwie członkowskim UE ma przede wszystkim bardzo aktualny wymiar praktyczny dla osób zarobkujących w tych formach i podmiotów ich zatrudniających. Jednocześnie jednak w tym temacie skupiają się najistotniejsze i najciekawsze zagadnienia międzynarodowej koordynacji systemów zabezpieczenia społecznego. Celem niniejszego artykułu jest zidentyfikowanie problemów występujących na tle prawnych kryteriów ustalania zakresu obowiązku składkowego obejmującego pracowników zatrudnionych w Polsce i wykonujących pracę na podstawie umów cywilnoprawnych $\mathrm{w}$ innym państwie członkowskim lub w innych państwach członkowskich UE. Wykorzystana zostanie metoda dogmatycznoprawnej analizy obowiązujących przepisów.

Skoro poruszamy się w ściśle regulowanych prawnie systemach ubezpieczeń społecznych poszczególnych państw posługujących się różnymi językami, to najważniejszą i wstępną sprawą jest ustalenie przyjmowanego przez stosujących te przepisy wspólnego rozumienia użytych pojęć i wynikające $\mathrm{z}$ tego odpowiednie zastosowanie reguł kolizyjnych określonych postanowieniami rangi międzynarodowej. W warunkach polskich nakładają się na to problemy właściwe dla polskiej regulacji, np. problem zakresu stosowania przepisów o zleceniobiorcach i osobach współpracujących czy okresach wykonywania przez nich stosownych 
umów. Tego rodzaju uwarunkowaniom ustalania składki na ubezpieczenia społeczne jest poświęcone niniejsze opracowanie.

Na pierwszy rzut oka może się - mylnie - wydawać, że wykonywanie umowy o pracę jest czymś całkowicie innym jakościowo od wykonywania umowy zlecenia, gdyż na różnicach między tymi dwiema formami zarobkowania koncentrujemy się w prawie polskim oraz w dotyczących go dyskusjach naukowych. Natomiast nieco inaczej wygląda to z dalszej perspektywy ponadsystemowej i ponadnarodowej. Kwestia opłacania składek jest wtórna w stosunku do ustaleń pierwotnych dotyczących określenia ustawodawstwa, które należy zastosować w danej sytuacji. Następnie stosuje się już właśnie to ustawodawstwo; jednak przynajmniej w pewnym zakresie musi ono uwzględniać szczególną sytuację osób aktywnych zarobkowo w różnych państwach.

W Unii Europejskiej koordynacja systemów ubezpieczeń społecznych odbywa się na podstawie następujących aktów prawnych:

- $\quad$ rozporządzenie Parlamentu Europejskiego i Rady (WE) nr 883/2004 z dnia 29 kwietnia 2004 r. w sprawie koordynacji systemów zabezpieczenia społecznego ${ }^{1}$;

- $\quad$ rozporządzenie Parlamentu Europejskiego i Rady (WE) nr 987/2009 z dnia 16 września 2009 r. dotyczące wykonywania rozporządzenia (WE) nr 883/2004 w sprawie koordynacji systemów zabezpieczenia społecznego ${ }^{2}$;

- $\quad$ rozporządzenie Parlamentu Europejskiego i Rady (UE) nr 1231/2010 z dnia 24 listopada $2010 \mathrm{r}$. rozszerzające rozporządzenie (WE) nr 883/2004 i rozporządzenie (WE) nr 987/2009 na obywateli państw trzecich, którzy nie są jeszcze objęci tymi rozporządzeniami jedynie ze względu na swoje obywatelstwo ${ }^{3}$.

1 Dz.Urz. UE L 166 z dnia 30 kwietnia 2004 r., s. 1-123; Polskie wydanie specjalne: Rozdział 05 Tom 005 P. 72-116 (dalej: rozporządzenie nr 883/2004 lub rozporządzenie podstawowe).

2 Dz.Urz. UE L 284 z dnia 30 października 2009 r., s. 1; dalej: rozporządzenie nr 987/2009 lub rozporządzenie wykonawcze. Wspólnie rozporządzenia nr 883/2004 i 987/2009 będą nazywane rozporządzeniami koordynującymi.

3 Dz.Urz. UE L 344 z dnia 29 grudnia 2010 r., s. 1-3. 
Akty te opierają się na założeniu, że w danym okresie dana osoba ma przynależeć do jednego systemu ubezpieczeń obowiązkowych, a więc w danej sytuacji należy stosować ustawodawstwo tylko jednego państwa. Jest to tzw. ustawodawstwo właściwe ${ }^{4}$. Ustawodawstwo takie określane jest zgodnie z przepisami tytułu II rozporządzenia nr 883/2004 (art. 11 ust. 1 i n.).

\section{Uwarunkowania ustalenia obowiązku składkowego w prawie europejskim}

W rozporządzeniu wyodrębniono tylko kilka kategorii osób objętych koordynacją. Dla każdej z tych kategorii wprowadzono normę kolizyjną wskazującą ustawodawstwo właściwe (art. 11 ust. 3 rozporządzenia nr 883/2004). W szczególności osoba wykonująca w państwie członkowskim pracę najemną lub pracę na własny rachunek podlega ustawodawstwu tego państwa członkowskiego (lit. a), a urzędnik służby cywilnej podlega ustawodawstwu państwa członkowskiego, jakiemu podlega zatrudniająca go administracja (lit. b). Ponadto wyodrębniono osoby otrzymujące zasiłek dla bezrobotnych (lit. c), osoby powołane lub odwołane ze służby w siłach zbrojnych lub służby cywilnej (lit. d) oraz „inne osoby”, do których nie mają zastosowania przepisy lit. a do d (lit. e). Geneza regulacji dotyczącej tej ostatniej grupy wskazuje, że chodzi o osoby nieaktywne zawodowo ${ }^{5}$.

Lista wyodrębnionych kategorii osób migrujących zawarta w art. 11 ust. 3 rozporządzenia nr 883/2004 jest zatem krótsza niż polska lista tytułów ubezpieczeń społecznych (przede wszystkim art. 6 ust. 1 pkt 1-22

\footnotetext{
4 Zgodnie z art. 1 lit. 1 rozporządzenia nr 883/2004 określenie „ustawodawstwo” oznacza, w odniesieniu do każdego państwa członkowskiego, przepisy ustawowe, wykonawcze i inne oraz obowiązujące środki wykonawcze odnoszące się do działów systemu zabezpieczenia społecznego objętych koordynacją.

5 Ze szczególnym uwzględnieniem zaprzestania działalności lub ubezpieczenia z różnych powodów (art. 11 ust. 2 rozporządzenia podstawowego); zob. np. pkt 18a preambuły do rozporządzenia podstawowego oraz F. Pennings, European Social Security Law, Antwerp-Oxford-Portland 2012, s. 83-88; K. Ślebzak, Koordynacja systemów zabezpieczenia społecznego, Warszawa 2010, s. 214.
} 
ustawy z dnia 13 października 1998 r. o systemie ubezpieczeń społecznych $^{6}$ ). W szczególności w interesującym nas zakresie wyodrębniono pracowników (art. 6 ust. 1 pkt 1 u.s.u.s.), czyli osoby pozostające w stosunku pracy (art. 8 ust. 1); zleceniobiorców, czyli osoby wykonujące pracę na podstawie umowy agencyjnej lub umowy zlecenia albo innej umowy o świadczenie usług, do której zgodnie z Kodeksem cywilnym stosuje się przepisy dotyczące zlecenia (pkt 4), oraz osoby prowadzące pozarolniczą działalność (pkt 5). Należy również uwzględniać osoby współpracujące ze zleceniobiorcami i osobami prowadzącymi pozarolniczą działalność ${ }^{7}$.

Jednocześnie celem unijnej regulacji koordynującej krajowe systemy zabezpieczenia społecznego jest realizacja założeń przyjętych w Traktacie o funkcjonowaniu Unii Europejskiej (TfUE). W dziedzinie zabezpieczenia społecznego mają być przyjęte środki niezbędne do ustanowienia swobodnego przepływu pracowników, a gwarancje mają dotyczyć migrujących pracowników najemnych i osób prowadzących działalność na własny rachunek (art. 47 TfUE). Pierwszeństwo musi być przyznane celom traktatowym i unijnemu rozumieniu poszczególnych pojęć ${ }^{8}$. Nie może wystąpić sytuacja, by niektóre z osób korzystających ze swobody przepływu, lecz w Polsce wiązanych ze szczególnym tytułem ubezpieczeń społecznych, były wyłączone z koordynacji. Dlatego pierwszoplanową rolę pełnią ustalenia wstępne.

Ze względu na pierwszeństwo stosowania rozporządzenia UE należy wyjść od tej właśnie regulacji i do niej niejako dostosować rozwiązania krajowe. W zakresie objętym niniejszym opracowaniem mamy do wyboru zakwalifikowanie danej osoby do grupy osób wykonujących w państwie

\footnotetext{
Tekst jedn. Dz.U. z 2016 r., poz. 963 ze zm. (dalej: u.s.u.s.).

Za osobę współpracującą z osobami prowadzącymi pozarolniczą działalność oraz zleceniobiorcami uważa się małżonka, dzieci własne, dzieci drugiego małżonka i dzieci przysposobione, rodziców, macochę i ojczyma oraz osoby przysposabiające, jeżeli pozostają z nimi we wspólnym gospodarstwie domowym i współpracują przy prowadzeniu tej działalności lub wykonywaniu umowy agencyjnej lub umowy zlecenia; nie dotyczy to osób, z którymi została zawarta umowa o pracę w celu przygotowania zawodowego (art. 8 ust. 11 u.s.u.s.).

$8 \quad$ Wyrok Trybunału z dnia 19 marca 1964 r. w sprawie 75-63, M.K.H. Unger, małżonce R. Hoekstra przeciwko Bestuur der Bedrijfsvereniging voor Detailhandel en Ambachten te Utrecht, ECLI:EU:C:1964:19, s. 347.
} 
członkowskim pracę najemną lub pracę na własny rachunek. Mimo że osoby należące do obydwu tych grup, zgodnie z przywołanym powyżej art. 11 ust. 3 lit. a rozporządzenia nr 883/2004, podlegają ustawodawstwu tego państwa członkowskiego, w którym wykonują pracę, rozróżnienie rodzajów działalności staje się istotne, gdy różne rodzaje pracy wykonywane są w różnych państwach. Ustawodawstwo właściwe ustala się wtedy bowiem nie zgodnie z ogólnym przepisem art. 11 ust. 3 rozporządzenia nr 883/2004, lecz na podstawie szczegółowego art. 13 ust. 3, który przewiduje, że osoba, która normalnie wykonuje pracę najemną i pracę na własny rachunek w różnych państwach członkowskich, podlega ustawodawstwu państwa członkowskiego, w którym wykonuje swą pracę najemną lub, jeżeli wykonuje taką pracę w dwóch lub w kilku państwach członkowskich, ustawodawstwu określonemu zgodnie ze stosownymi przepisami ${ }^{9}$. To dlatego rozwiązanie praktycznego problemu, jakie składki należy zapłacić, zależy od zakwalifikowania wykonywanych prac jako jednorodzajowych (art. 11 ust. 1 lit. a lub art. 13 ust. 1 lub 2) albo wykonywanych w różnych określonych rozporządzeniem formach.

Zgodnie z art. 1 lit. a rozporządzenia nr 883/2004 określenie „praca najemna” oznacza wszelką pracę lub sytuację równoważną, traktowaną jako taką do celów stosowania ustawodawstwa w zakresie zabezpieczenia społecznego państwa członkowskiego, w którym taka praca lub sytuacja równoważna ma miejsce. Natomiast „działalność na własny rachunek” to wszelka praca lub sytuację równoważna, traktowana jako taka do celów ustawodawstwa w zakresie zabezpieczenia społecznego państwa członkowskiego, w którym taka praca lub sytuacja równoważna ma miejsce (lit. b). Obie definicje odwołują się do definicji z państwa członkowskiego, w którym dana sytuacja ma miejsce ${ }^{10}$. W obu państwach mogą wystę-

$9 \quad$ Zob. np. T. Bińczycka-Majewska, Koordynacja systemów zabezpieczenia społecznego w Unii Europejskiej, Kraków 1999, s. 134; T. Major, B. Pawłowska, Ubezpieczenie społeczne migrujqcych pracowników oraz osób prowadzq̨cych działalność gospodarczq, Warszawa 2010, s. 170; M. Tomaszewska, Zakres podmiotowy europejskiego prawa zabezpieczenia społecznego [w:] S. Majkowska-Szulc, M. Tomaszewska, M. Zieleniecki, Zabezpieczenie społeczne w Unii Europejskiej, Warszawa 2012, s. 57-59.

10 Wyroki TS UE z dnia 30 stycznia 1997 r.: w sprawie C-340/94 E.J.M. de Jaeck przeciwko Staatssecretaris van Financiën, ECLI:EU:C:1997:43, pkt 22-23, 34; a także 
pować zatem, co wyraźnie dopuszcza brzmienie rozporządzenia, różne ujęcia danego rodzaju pracy. Nawet jeżeli faktycznie praca wykonywana w obu państwach ma takie same cechy, w każdym z państw może być zakwalifikowana inaczej. Należy zatem przyjąć, że ustalenia w tej kwestii należą do organów danego państwa ${ }^{11}$.

Ze względu na dychotomię praca najemna - praca na własny rachunek w polskiej koordynacji systemów zabezpieczenia społecznego od początku przyjęto, że określenie „praca najemna” obejmuje pracę na podstawie umowy o pracę, umowy zlecenia oraz osoby duchowne ${ }^{12}$. A zatem praca wykonywana na podstawie umów zlecenia i innych umów o świadczenia usług jest pracą traktowaną jak zatrudnienie pracownicze, według obecnej terminologii - pracą najemną. Skoro uzyskuje się wynagrodzenie z jednego źródła, to bliżej takim osobom do „personne qui exerce une activité salariée” (wersja francuska) lub „person who pursues an activity as an employed person” (wersja angielska), niż do odpowiednio „une activité non salariée” albo „an activity as a self-employed person”. Nie przesądza to jednak o tym, że praca, którą w Polsce potraktowalibyśmy jako pracę w warunkach charakterystycznych dla umowy o świadczenie usług, czyli jako zleceniobiorca, w państwie jej wykonywania również będzie traktowana jako praca najemna.

w sprawie C-221/95 Institut National d'Assurances Sociales pour Travailleurs Indépendants (Inasti) przeciwko Claude Hervein i Hervillier S.A., ECLI:EU:C:1997:47, pkt 22; Wyrok Trybunału (czwarta izba) z dnia 27 września 2012 r. w sprawie C-137/11, Partena ASBL przeciwko Les Tartes de Chaumont-Gistoux SA, ECLI:EU:C:2012:593, pkt 50.

11 Zob. procedura przewidziana w art. 16 rozporządzenia nr 987/2009, a także art. 7 tego rozporządzenia, zgodnie z którym o ile rozporządzenie wykonawcze nie stanowi inaczej, w przypadku, gdy dana osoba jest zobowiązana do zapłacenia składki zgodnie $\mathrm{z}$ rozporządzeniem podstawowym, natomiast instytucja właściwa nie posiada wszystkich informacji dotyczących jej sytuacji w innym państwie członkowskim niezbędnych do ostatecznego wyliczenia składki, instytucja ta - na wniosek zainteresowanego - dokonuje tymczasowego wyliczenia wysokości składki, jeżeli takie wyliczenia są możliwe na podstawie informacji, które instytucja ta posiada. Świadczenie lub składka wyliczane są ponownie, gdy tylko instytucja zainteresowana otrzyma wszystkie niezbędne dowody potwierdzające lub dokumenty. Zob. także wyrok Sądu Okręgowego w Poznaniu z dnia 22 września 2016 r., sygn. VIII U 2730/15.

12 Zob. Zasady wypełniania zaświadczenia A1, http://www.zus.pl/default.asp?p=7\&id=105\#p215, dostęp: 11.01.2017 r. 
Niezależnie od ustaleń dotyczących kwalifikacji pracy wykonywanej w różnych państwach znaczenie w ustalaniu ustawodawstwa właściwego może mieć również rozmiar wykonywanej pracy. Zgodnie z art. 14 ust. 5b rozporządzenia nr 987/2009 praca o charakterze marginalnym nie będzie brana pod uwagę do celów określenia mającego zastosowanie ustawodawstwa na mocy art. 13 rozporządzenia podstawowego. Jednocześnie jednak procedura dotycząca stosowania przepisów określających ustawodawstwo właściwe ma zastosowanie również przy wykonywaniu takiej marginalnej pracy (art. 16 rozporządzenia wykonawczego) ${ }^{13}$. Przyjmuje się, że praca o marginalnym charakterze to praca, która jest stała, ale ma niewielkie znaczenie pod względem czasu oraz zysku ekonomicznego. Zaleca się, aby przyjąć wskaźnik, zgodnie z którym za pracę o marginalnym charakterze uznawać będzie się pracę zajmującą mniej niż 5\% regularnego czasu pracy pracownika i/lub przynoszącą mniej niż 5\% jego całkowitego wynagrodzenia. Charakter wykonywanej pracy, np. praca o charakterze pomocniczym, pozbawiona niezależności, wykonywana w domu lub w służbie dla głównej pracy, może również posłużyć za wskaźnik pracy o charakterze marginalnym. Osoba, która wykonuje „pracę o charakterze marginalnym” w jednym państwie członkowskim i pracuje również w innym państwie członkowskim, nie może być uznawana za osobę normalnie wykonującą pracę w dwóch lub w kilku państwach członkowskich i w związku z tym nie jest objęta przepisami art. 13 rozporządzenia nr $883 / 2004^{14}$.

Ta regulacja wydaje się szczególnie ważna ze względu na często występującą w Polsce praktykę zawierania przez osoby pozostające w stosunku pracy, nawet w pełnym wymiarze czasu pracy, dodatkowych umów cywilnoprawnych, pojedynczych lub wielu, niekiedy dotyczących prac

13 Osoba, która wykonuje pracę w dwóch lub więcej państwach członkowskich, informuje o tym instytucję wyznaczoną przez właściwą władzę państwa członkowskiego, w którym ma miejsce zamieszkania. Ta instytucja niezwłocznie ustala ustawodawstwo mające zastosowanie do zainteresowanego, uwzględniając art. 13 rozporządzenia podstawowego oraz art. 14 rozporządzenia wykonawczego.

14 European Commission, Employment Social Affaires and Equal Opportunities, Praktyczny poradnik: Ustawodawstwo majqce zastosowanie do pracowników w Unii Europejskiej (UE), Europejskim Obszarze Gospodarczym (EOG) i Szwajcarii, 2013, s. 30. 
dorywczych lub wykonywanych w niewielkim zakresie. Część z tych umów cywilnoprawnych zawierana jest za granicą. Wprowadzenie w 2012 r. szczególnej regulacji dotyczącej pracy o charakterze marginalnym $^{15}$ miało na celu zapobieżenie przypadkom manipulowania zasadami określającymi mające zastosowanie ustawodawstwo. Dlatego praca taka nie jest brana pod uwagę przy ustalaniu ustawodawstwa właściwego - tak jakby na tym etapie przyjmowało się, że dana osoba nie pracuje w danym państwie. I tak musi być ona jednak zgłoszona w procedurze ustalania ustawodawstwa właściwego zgodnie z rozporządzeniem wykonawczym, chociażby w celu oceny jej charakteru i zakresu.

Ze względu na te przepisy stosunkowo często do polskich pracowników wykonujących jednocześnie umowy cywilnoprawne w innych państwach członkowskich będzie miało zastosowanie ustawodawstwo polskie. Wykonywanie umów cywilnoprawnych ma bowiem często charakter „okazjonalnego dorabiania”, a nie istotnego źródła utrzymania. Ich los będzie jednak zależał od właściwych przepisów polskich. Marginalnej pracy nie uwzględnia się przy ustalaniu ustawodawstwa, ale - jak zaraz będziemy rozważać - niekoniecznie oznacza to, że nie będzie trzeba opłacić od niej składki. Ponadto trzeba jeszcze pamiętać o bardzo kontrowersyjnym polskim przepisie art. 8 ust. 2a u.s.u.s.

Podsumowując, formalnie stosunek pracy w Polsce i wykonywanie umowy cywilnoprawnej w innym państwie może oznaczać dwie sytuacje różnie uregulowane w rozporządzeniach koordynujących:

1) praca najemna - praca najemna, gdyż wykonywanie umów cywilnoprawnych dla celów koordynacji traktuje się jako „pracę najemną”16. w takim przypadku ustawodawstwo właściwe należy ustalać na podstawie art. 13 ust. 1 rozporządzenia podstawowego;

15 Art. 2 pkt 1 lit. b rozporządzenia Parlamentu Europejskiego i Rady (UE) nr 465/2012 z dnia 22 maja 2012 r. zmieniającego rozporządzenie (WE) nr 883/2004 w sprawie koordynacji systemów zabezpieczenia społecznego oraz rozporządzenie (WE) nr 987/2009 dotyczące wykonywania rozporządzenia (WE) nr 883/2004, Dz.Urz. UE L 149 z dnia 8 czerwca 2012, s. 4-10.

16 Nie wydaje się, żeby de lege lata inne traktowanie w poszczególnych państwach było częste, tym bardziej że w wielu krajach, podobnie jak w Polsce, rozgraniczenie umów cywilnoprawnych i umów o pracę nie jest ostre. 
2) praca najemna - praca na własny rachunek (działalność); a wtedy zastosowanie znajduje art. 13 ust. 3 rozporządzenia podstawowego. Wydaje się jednak, że będzie to sytuacja wyjątkowa ${ }^{17}$ ze względu na dominujące okoliczności zawierania umów cywilnoprawnych przez polskich pracowników za granicą.

Należy jednak odnotować, że w art. 13 ust. 3 rozporządzenia podstawowego, który przesądza, że osoba, która normalnie wykonuje pracę najemną ${ }^{18} \mathrm{i}$ pracę na własny rachunek w różnych państwach członkowskich, podlega ustawodawstwu państwa, w którym wykonuje swą pracę najemną, nie występują żadne wymogi dotyczące rozmiaru pracy najemnej. Stosunek pracy przeważa nad prowadzoną działalnością, podobnie jak w art. 9 ust. 1 polskiej u.s.u.s. ${ }^{19}$ Może to mieć istotne znaczenie w zestawieniu z regulacją nakazującą nie uwzględniać przy ustalaniu ustawodawstwa właściwego pracy o marginalnym charakterze (art. 14 ust. 5b rozporządzenia nr 987/2009). Nie ma postanowienia koordynującego, które w szczególny sposób regulowałoby taką sytuację. Jednak wydaje się, że przy rozstrzyganiu pierwszeństwo należałoby przyznać postanowieniu określającemu, które aktywności zawodowe są traktowane jako łączniki przy ustalaniu ustawodawstwa właściwego, a więc zakres stosowania regulacji kolizyjnej (art. 14 ust. 5b rozporządzenia nr 987/2009), a dopiero po ewentualnym wyłączeniu pracy o charakterze marginalnym - postanowienia określające ustawodawstwo właściwe. W ramach tego drugiego etapu stosunek pracy bezwzględnie przeważa, niezależnie od jego rozmiaru. Wystarczy, że jest to rozmiar większy niż marginalny.

17 Na przykład sytuacja taka mogłaby wystąpić, jeśli prawo danego państwa dopuszczałoby wykonywanie pracy jako członek zarządu spółki handlowej na podstawie umowy zlecenia.

W szerokim unijnym rozumieniu, obejmującym również osoby pozostające w służbie publicznej danego państwa: wyrok Trybunału (trzecia izba) z dnia 24 marca 1994 r. w sprawie C-71/93 Guido Van Poucke przeciwko Rijksinstituut voor de Sociale Verzekeringen der Zelfstandigen i Algemene Sociale Kas voor Zelfstandigen, ECLI:EU:C:1994:120, pkt 15-19.

19 Z zastrzeżeniem art. 9 ust. 1a u.s.u.s., czyli jeżeli podstawa wymiaru składek z tytułu stosunku pracy w przeliczeniu na okres miesiąca nie jest niższa od minimalnego wynagrodzenia za pracę. 
Powyższe rozważania zmierzały do uporządkowania zasad określania ustawodawstwa właściwego dla osób pozostających w Polsce w stosunku pracy i wykonujących za granicą umowy cywilnoprawne. Na następnym etapie to określone ustawodawstwo właściwe wyznacza, jakie są zasady a przede wszystkim zakres - opłacania składek, czyli reguluje konsekwencje zbiegu tytułów ubezpieczenia i wysokość opłacanych składek.

\section{Uwarunkowania ustalania obowiązku składkowego i jego zakresu w prawie polskim}

Najczęściej osoba będąca w Polsce pracownikiem ma tu miejsce zamieszkania i wykonuje tu znaczną część pracy ${ }^{20}$. Do takiej sytuacji stosuje się prawo polskie, nawet jeżeli dana osoba wykonuje pracę najemną w rozumieniu rozporządzeń koordynujących (czyli także w formach cywilnoprawnych) w innym państwie członkowskim (art. 13 ust. 1 lit. a rozporządzenia podstawowego). Skoro taka sytuacji jest najbardziej prawdopodobna, na niej się skupmy.

Należy przy tym pamiętać o przyjętej w unijnej koordynacji zasadzie równego traktowania świadczeń i dochodów. Na podstawie art. 5 lit. a rozporządzenia nr 883/2004 w przypadkach, w których na podstawie ustawodawstwa właściwego państwa członkowskiego, otrzymywanie świadczeń z zabezpieczenia społecznego i inny dochód ma pewne skutki prawne, odpowiednie przepisy tego ustawodawstwa mają zastosowanie także do dochodów osiągniętych w innym państwie członkowskim (z dopuszczeniem wyjątków przewidzianych w rozporządzeniach koordynujących). Natomiast na podstawie art. 13 ust. 5 rozporządzenia $\mathrm{nr}$ 883/2004 już po ustaleniu ustawodawstwa właściwego ${ }^{21}$ do celów stoso-

20 Nie musi to być koniecznie największa część pracy. Proporcja mniejsza niż 25\% czasu pracy lub wynagrodzenia wskazuje, że znaczna część pracy nie jest wykonywana w danym państwie członkowskim (art. 14 ust. 8 rozporządzenia wykonawczego).

21 Wniosek taki sugeruje również pkt 11 preambuły do rozporządzenia nr 883/2004, z którego wynika, że uwzględnianie okoliczności lub wydarzeń mających miejsce w państwie członkowskim nie może w żaden sposób sprawiać, że właściwym dla nich stanie się inne państwo ani że będzie się do nich stosować jego ustawodawstwo; zob. M. Zieliński, Równe traktowanie świadczeń, dochodów, okoliczności lub zdarzeń na 
wania ustawodawstwa określonego zgodnie z przepisami art. 13 ust. 1 do 4 rozporządzenia podstawowego osoby wykonujące pracę w dwóch lub w kilku państwach członkowskich są traktowane tak, jak gdyby wykonywały każdą swoją pracę najemną lub pracę na własny rachunek i jakby uzyskiwały cały swój dochód w zainteresowanym państwie członkowskim. Przepis ten jednoznacznie przesądza, że stosowanie ustawodawstwa właściwego może wiązać się z pobieraniem składek od przychodów uzyskiwanych w innym państwie członkowskim niż to, do którego składki mają trafić. Chodzi o to, żeby uniknąć sytuacji, że nie wszystkie rodzaje aktywności danej osoby będą pokryte jakimkolwiek ustawodawstwem zabezpieczenia społecznego ${ }^{22}$.

W praktyce zasada ta oznacza, że dla celów ustalania składki na ubezpieczenia społeczne w Polsce do wynagrodzenia uzyskiwanego w innym państwie członkowskim z tytułu umowy cywilnoprawnej stosujemy przepisy polskie, a więc traktujemy je jak wynagrodzenie uzyskiwane w Polsce. Na przykład dla celu ustalenia zakresu podlegania obowiązkowi ubezpieczeń społecznych i ustalania wysokości podstawy wymiaru składki ${ }^{23}$ można i należy zliczać kwoty uzyskane w różnych państwach.

Stosując prawo polskie do pracownika zatrudnionego w Polsce, który wykonuje jednocześnie umowę cywilnoprawną za granicą, należy wyróżnić co najmniej trzy sytuacje, w tym dwie, które można uznać za swoiste dla prawa polskiego.

Po pierwsze, osoba pozostająca w Polsce w stosunku pracy w pełnym wymiarze czasu pracy wykonuje za granicą umowę cywilnoprawną na rzecz podmiotu zagranicznego niebędącego jej pracodawcą. Z tytułu sto-

gruncie rozporzqdzenia $\mathrm{nr}$ 883/2004 - zagadnienia wybrane [w:] Z. Niedbała (red. nauk.), Prawo wobec dyskryminacji w życiu społecznym, gospodarczym i politycznym, Warszawa 2011, s. 308.

Wyrok TS UE z dnia 30 stycznia 1997 r w sprawie C-221/95 Institut National d'Assurances Sociales pour Travailleurs Indépendants (Inasti) przeciwko Claude $\mathrm{He}$ rvein i Hervillier S.A., ECLI:EU:C:1997:47, pkt 60.

23 Zob. np. K. Ślebzak, Koordynacja..., s. 249; por. także art. 21 ust. 2 rozporządzenia wykonawczego, na którego podstawie pracodawca niemający miejsca prowadzenia działalności w państwie członkowskim, którego ustawodawstwo ma zastosowanie, może uzgodnić z pracownikiem, że spoczywający na pracodawcy obowiązek zapłacenia składek może być wypełniany w jego imieniu przez pracownika. 
sunku pracy uzyskuje zatem co najmniej minimalne wynagrodzenie za pracę. Podlega więc obowiązkowo polskim ubezpieczeniom społecznym tylko z tytułu stosunku pracy (art. 9 ust. 1 u.s.u.s.). Jednak jeżeli podstawa wymiaru składek na ubezpieczenia emerytalne i rentowe z tytułu stosunku pracy takiej osoby jest niższa od minimalnego wynagrodzenia za pracę, podlega ona również obowiązkowo ubezpieczeniom emerytalnemu i rentowym z innych tytułów, w tym z zagranicznej umowy cywilnoprawnej (art. 9 ust. 1a u.s.u.s.). Dotyczy to zatem jedynie pracowników zatrudnionych w niepełnym wymiarze czasu pracy, gdyż tylko oni nie mają udzielonej przez prawo polskie gwarancji uzyskania minimalnego wynagrodzenia za pracę.

Po drugie, może wystąpić sytuacja, że umowa cywilnoprawna dotycząca pracy za granicą jest zawarta z podmiotem, który jest jednocześnie pracodawcą danego ubezpieczonego. Międzynarodowe kolizyjne konsekwencje takiej umowy muszą być przede wszystkim rozstrzygane na podstawie art. 12 rozporządzenia nr 883/2004 i są uzależnione od tego, czy spełnione są warunki uznania danej osoby za pracownika delegowanego w rozumieniu rozporządzeń koordynujących.

Jeżeli tak, w pełni powinien tu znaleźć zastosowanie art. 8 ust. 2a u.s.u.s., według którego za pracownika uważa się także osobę wykonującą pracę na podstawie umowy agencyjnej, umowy zlecenia lub innej umowy o świadczenie usług, do której zgodnie z Kodeksem cywilnym stosuje się przepisy dotyczące zlecenia, albo umowy o dzieło, jeżeli umowę taką zawarła z pracodawcą, z którym pozostaje w stosunku pracy, lub jeżeli w ramach takiej umowy wykonuje pracę na rzecz pracodawcy, z którym pozostaje w stosunku pracy. W konsekwencji w podstawie wymiaru składek na ubezpieczenia społeczne uwzględnia się również przychód z tytułu umowy agencyjnej, umowy zlecenia lub innej umowy o świadczenie usług, do której zgodnie z Kodeksem cywilnym stosuje się przepisy dotyczące zlecenia albo umowy o dzieło (art. 18 ust. 1a u.s.u.s.). Składki powinny być zatem opłacone, zgodnie z polskimi przepisami, od całości przychodu uzyskiwanego z tytułu stosunku pracy lub pracy wykonywanej na rzecz pracodawcy na podstawie umowy cywilnoprawnej. 
Jeżeli nie ma podstaw do uznania danej osoby za pracownika delegowanego, to powinna być ona potraktowana jak osoba, która normalnie wykonuje pracę najemną w dwóch lub więcej państwach członkowskich (art. 13 ust. 1 rozporządzenia nr 883/2004). Jednak dla osób zamieszkałych w Polsce i wykonujących tu znaczną część pracy oznacza to stosowanie prawa polskiego, a w tym również art. 8 ust. 2a u.s.u.s. i art. 18 ust. 1a u.s.u.s. A zatem, co wydaje się dość zaskakujące, podstawa ustalenia ustawodawstwa właściwego nie wpływa na zakres obowiązku składkowego i ustalanie podstawy wymiaru składek. Sytuacja wyglądałaby zupełnie inaczej, gdyby właściwe okazało się inne ustawodawstwo ${ }^{24}$.

Przypomnijmy, że sytuacja, gdy umowa cywilnoprawna dotyczyłaby pracy za granicą, która nie byłaby wykonywana na rzecz polskiego podmiotu będącego jednocześnie pracodawcą danej osoby, podlegałaby już ogólnym regułom ustalania ustawodawstwa właściwego. W pierwszej kolejności należy sprawdzić, czy można zastosować wyjątek dotyczący pracowników delegowanych (w zakresie umowy cywilnoprawnej), co oznaczałoby dalsze stosowanie prawa polskiego (art. 12 rozporządzenia podstawowego). W tym przypadku jednak nie byłoby już podstaw do zastosowania art. 8 ust. 2a u.s.u.s., a więc składki byłyby płacone jedynie od przychodu uzyskiwanego $\mathrm{z}$ tytułu umowy o pracę (art. 9 ust. 1 u.s.u.s. $)^{25}$. Jeżeli nie dochodziłoby do delegowania pracownika, ustawodawstwo właściwe byłoby ustalane zgodnie z postanowieniami dotyczącymi osób, które wykonują normalnie pracę w różnych państwach członkowskich (art. 13 rozporządzenia nr 883/2004). Jeżeli wskazywane byłoby prawo polskie, również prowadziłoby to do wyłączenia obowiązku opłacania składki z tytułu umowy cywilnoprawnej na warunkach określonych w art. 9 u.s.u.s.

Po trzecie, należy zasygnalizować, że z punktu widzenia koordynacji systemów zabezpieczenia społecznego w UE bardzo podobnie wygląda sytuacja osoby, która w Polsce jest uznawana za zleceniobiorcę (art. 6 ust. 1 pkt 4 u.s.u.s.) i jednocześnie wykonuje w innym państwie umowy cy-

24 Na przykład pod pewnymi warunkami dla osób niezamieszkałych w Polsce - art. 13 ust. 1 lit. rozporządzenia podstawowego.

25 Oczywiście po spełnieniu wszystkich warunków przewidzianych przez art. 9 u.s.u.s. 
wilnoprawne. Jeżeli (zgodnie z regułami kolizyjnymi rozporządzeń koordynujących) właściwe jest prawo polskie, to taka osoba ma obowiązek opłacać składki w zakresie wynikającym z art. 9 u.s.u.s., w pewnym uproszczeniu - głównie w zależności od podstawy wymiaru składek na ubezpieczenia emerytalne i rentowe z poszczególnych umów w danym miesiącu ${ }^{26}$. Nie można więc wykluczyć obowiązku odprowadzania składek od przychodu uzyskiwanego na podstawie zagranicznych umów do polskiego systemu.

\section{Uwagi końcowe}

Powyższe rozważania służyły zidentyfikowaniu prawnych problemów dotyczących ustalania zobowiązań z tytułu składek na ubezpieczenia społeczne za pracowników zatrudnionych w Polsce i wykonujących pracę na podstawie umów cywilnoprawnych w innym państwie członkowskim (lub w innych państwach członkowskich) UE. Na obowiązek składkowy silnie wpływa dwukrotna regulacja nakazująca uwzględnianie dochodów z innych państw członkowskich: dla ustalenia ustawodawstwa właściwego (art. 5 lit. b rozporządzenia podstawowego) oraz następnie przy stosowaniu ustalonego ustawodawstwa właściwego (art. 13 ust. 5 rozporządzenia podstawowego).

Należy podkreślić, że jeżeli właściwe jest ustawodawstwo polskie, może dochodzić do obowiązku opłacenia składek od przychodów uzyskiwanych z tytułu umowy cywilnoprawnej wykonywanej za granicą, choć w praktyce będzie to raczej sytuacja wyjątkowa. Zgodnie z zasadą równego traktowania dochodów z innych państw członkowskich nie powinno dochodzić do szczególnego różnicowania zasad opłacania składek w zależności od źródła pochodzenia przychodu, od którego są opłacane.

26 Osoba będąca zleceniobiorcą, której podstawa wymiaru składek na ubezpieczenia emerytalne i rentowe w danym miesiącu jest niższa od minimalnego wynagrodzenia za pracę, spełniająca warunki do objęcia obowiązkowo ubezpieczeniami emerytalnym i rentowymi z innych tytułów, podlega obowiązkowo ubezpieczeniom emerytalnemu i rentowym również z innych tytułów (art. 9 ust. 2c u.s.u.s.). 
Z punktu widzenia ubezpieczonych szczególnie istotne jest, że niezależnie od źródła finansowania i pochodzenia składek, po ich opłaceniu są one traktowane jako składki w ramach polskiego systemu ubezpieczeń społecznych. Stanowią one następnie podstawę nabywania uprawnień i są brane pod uwagę przy obliczaniu ich wysokości. Jako przykład można wskazać podstawę obliczania emerytury z uwzględnieniem kwot zewidencjonowanych na koncie ubezpieczonego i subkoncie ${ }^{27}$ lub wyliczanie podstawy wymiaru zasiłków od podstawy wymiaru składek ${ }^{28}$. W tych przypadkach szczegółowe odnoszenie zasad ustalania podstawy wymiaru składek i podstawy wymiaru świadczeń wynagrodzenia za pracę i za wykonywanie umów cywilnoprawnych do obcego prawa regulującego składniki wynagrodzenia za pracę w różnych formach (wynagrodzenia za pracę i za wykonywanie umów cywilnoprawnych) może powodować dalsze problemy ${ }^{29}$. Co do zasady należy kierować się regułą, że mimo możliwych odmienności, osoby migrujące mają być traktowane tak, jakby uzyskiwały cały swój dochód w zainteresowanym państwie członkowskim.

\section{Bibliografia:}

Bińczycka-Majewska T., Koordynacja systemów zabezpieczenia społecznego w Unii Europejskiej, Zakamycze, Kraków 1999.

Tomaszewska M., Zakres podmiotowy europejskiego prawa zabezpieczenia społecznego [w:] Majkowska-Szulc, S., Tomaszewska, M., Zieleniecki, M., Zabezpieczenie społeczne w Unii Europejskiej, Instytut Wydawniczy EuroPrawo, Warszawa 2012.

27 Art. 25 ustawy z dnia 17 grudnia 1998 r. o emeryturach i rentach z Funduszu Ubezpieczeń Społecznych (tekst jedn. Dz.U. 2016 r. poz. 887 ze zm.).

28 Art. 36 w zw. z art. 3 pkt 3 oraz art. 48 ust. 4 w zw. z art. 4 ustawy z dnia 25 czerwca 1999 r. o świadczeniach pieniężnych z ubezpieczenia społecznego w razie choroby i macierzyństwa (tekst jedn. Dz.U. z 2016 r. poz. 372 ze zm.).

29 Np. w kontekście § 5 rozporządzenia Ministra Pracy i Polityki Socjalnej z dnia 18 grudnia 1998 r. w sprawie szczegółowych zasad ustalania podstawy wymiaru składek na ubezpieczenia emerytalne i rentowe (tekst jedn. Dz.U. 2015 r. poz. 2236). 
Major T., Pawłowska, B., Ubezpieczenie społeczne migrujq̨cych pracowników oraz osób prowadzq̨ych działalność gospodarczq, Wydawnictwo C.H. Beck, Warszawa 2010.

Pennings F., European Social Security Law, Intersentia, Antwerp-OxfordPortland 2010.

Ślebzak K., Koordynacja systemów zabezpieczenia społecznego, Lex a Wolters Kluwer business, Warszawa 2012.

Zieliński M., Równe traktowanie świadczeń, dochodów, okoliczności lub zdarzeń na gruncie rozporzq̨dzenia $\mathrm{nr}$ 883/2004 - zagadnienia wybrane [w:] Z. Niedbała (red. nauk.), Prawo wobec dyskryminacji w życiu społecznym, gospodarczym i politycznym, Difin, Warszawa 2011. 